To cite this article: Lolade Funmi Osinulu (2020) Awareness and Use of Electronic Information Resources by Students of College of Health Sciences in Olabisi Onabanjo University, Nigeria. Information Impact: Journal of Information and Knowledge Management, 11:3, 1-11, DOI: https://dx.doi.org/10.4314/iijikm.v11i3.1

To link to this article: https://dx.doi.org/10.4314/iijikm.v11i3.1

\title{
Awareness and Use of Electronic Information Resources by Students of College of Health Sciences in Olabisi Onabanjo University, Nigeria
}

\author{
Lolade Funmi Osinulu \\ Obafemi Awolowo College of Health Sciences Library, Olabisi Onabanjo University, Sagamu, Ogun State, Nigeria
}

Abstract

The study examined awareness and use of electronic Information Resources (EIR) among students in College of Health Sciences, Sagamu, Nigeria. The objectives were to establish types of resources available, determine level of awareness, extent of the use of e-resources and problems faced. Descriptive survey design with real-time observation method was used to collect data using a structured questionnaire. The population comprised 2000 students in the College while purposive sampling technique was used to select a sample of 200 registered library users for the 2019/2020 academic session. Data was analyzed using descriptive statistics. The findings revealed that majority of the students were not aware of available EIR. It also revealed low frequent usage. The finding indicated that few respondents used EIR for academic purposes. However, inadequate computers, irregular power supply and slow internet speed were identified as major constraints using EIR. Upgrade of infrastructure, adoption of appropriate social media tools to promote awareness and collaborative effort by librarians and faculty members to train students the use of specialized databases were recommended.

Keywords Electronic information resources, awareness, use, Undergraduates, students, health sciences

CONTACT Lolade Funmi Osinulu osinululolade@gmail.com Obafemi Awolowo College of Health Sciences Library, Olabisi Onabanjo University, Sagamu, Ogun State, Nigeria.

2020 The Authors Published with License by Information Impact 


\section{Introduction}

The emergence of online databases or electronic information resources (EIR) arising from advancement in Information and Communication Technology (ICT) has brought changes to teaching, learning and research activities in Nigerian Universities. Consequently, EIR are becoming crucial in academic libraries because of the unique benefits to users and libraries providing unlimited and easy access to current information, obliterating space problem and promoting collaborative efforts in research (Yebowaah \& Plockey, 2017; Okello-Obura \& Magara 2008). Equally, integration of traditional library materials and electronic information resources coupled with the application of ICT has improved the quality of academic library services. The traditional library has transformed into digital or hybrid library where information resources migrate from print to electronic resources thereby making library operations become electronically driven. The new trend is affecting and influencing demand and preference in collection development practices. Consequently, most academic libraries including medical libraries in Nigerian universities are providing access to a variety of electronic information resources to allow for various types of searching facilities and promote scholarship (Tella et al., 2007).

Electronic information resources are electronic version of print formats which is a crucial part of library collection in the digital era. They are materials requiring computer access using desktops or handheld mobile devices such as Ipad, laptop and Smartphone in the library or at home for the purpose of teaching, studying and or research. Electronic Information Resources include databases (online and offline), E-books, E-journals, E-newspapers, E-research reports and E-lecture notes. Others are theses/dissertation, indexing and abstracting, reference databases such as bibliographies, dictionaries as well as sounds and files (IFLA, 2012).

Hitherto, the universe of knowledge was mainly in the form of print while libraries served as link between students and information sources, using manual method to retrieve and disseminate information. The method was considered inadequate in the digital era. The use of the Internet and WWW has made accessibility to remote databases and full text online resources possible. This trend is changing the expectations of users and opportunities to access information in different formats without restriction of space and time (Kumar, 2009). As a result, most academic libraries are becoming libraries without walls and are subscribing heavily to different databases and e-resources related to their institutional curriculum to provide better service. This development has not only improved library collection development practices and service provision but has also influenced users' searching behaviors. Students now have prompt access to diverse and quality information at the right time through the click of a button.

\section{Background information}

Olabisi Onabanjo University (OOU) formerly known as Ogun State University was established in January 1983 by the Ogun State Government, Nigeria. The university is a multi-campus institution. The main campus is situated in Ago-Iwoye in the Ijebu zone. The other three campuses are spread across the three other geo-political zones of the State namely Egba,Yewa and Remo. The Obafemi Awolowo College of Health Sciences (OACHS) situated in the Remo zone comprises the faculties of Pharmacy, Basic Medical Sciences and Clinical Sciences. The philosophy and objectives of the programmes are to train and mould future health professionals that would improve human health through research and provide solution to disease trends in the state and country in general. In support of the programmes, Olabisi Onabanjo University library (OOULIB) provides access to a variety of information resources: print and electronic formats. Online databases such as e-journals from subscribed databases: JSTOR, 
Science Direct, HINARI, offline CD-ROMs, E-books databases and E-Theses/Dissertations are provided to support teaching, learning and research activities. These resources are accessible 24/7 to registered library patrons including students through OPAC and library portal and in their homes with the use of appropriate password. The library is also equipped with computers, UPS, lumen projector, printer and wireless router.

However, in spite of the benefits, investment and capital outlay on subscription to electronic information resources and facilities, it has been observed that students are either not aware and or not making optimum use of these vital resources. Of what benefits are resources when they are not utilized for the purpose for which they are acquired? Recognizing the fact that the use of resources is part of assessment performance in academic libraries, librarians are increasingly concerned with the use of library products and services. This study attempts to investigate the extent of awareness, use and challenges in exploiting the electronic resources in the College library. To achieve this, the following research questions are raised to guide the study.

\section{Research questions}

1. What are the types of electronic information resources available in the library?

2. What is the level of the students' awareness of electronic information resources for use in the library?

3. What are the purpose(s) for which students use library electronic information resources?

4. How frequently do the students use electronic information resources available in the library?

5. What are the problems hindering the use of electronic information resources in the library by students?

\section{Literature review}

Electronic information resources form an integral part of library's collection and is becoming essential information requirement for learning, teaching and research activities in the digital era. Recently, in view of the inherent benefits of EIR, several studies have appraised awareness and use of electronic information resources (EIR) among students. Jogan (2015) in a study on use and impact of electronic resources in Institute of Technology, Delhi found that the usage of electronic journals is increasing due to awareness among the users. Kumar \& Kumar (2010) found in his study of medical and management Colleges in Bangalore that the users are well aware of e-resources and prefer to use internet. On the other hand, Bamidele (2015) asserted that most library users are unaware of the quality and variety of information available in academic libraries owing to inadequate knowledge. Ahmed (2013) conducted a survey of students' use and satisfaction with university subscribed online resources in a university in a developing country. The result revealed that many students did not use university subscribed resources. Also, Kinengyere (2007) found that available information resources are not accessed by users while Aina (2014) reported that inadequacy of EIR affect accessibility and use. However, Popoola (2008) opined that availability of resources does not mean use; while Natarajah, et al. (2010) cited in Igbo and Imo (2013) disclosed that with the availability of resources, frequency of use was still low. Dukper, Sakibu \& Arthur (2018) reported a low level of awareness of electronic resources among students with $61 \%$ unaware of the availability, $37 \%$ used the electronic resources once a week and $31 \%$ used it twice a week. Mandale (2019) examined the use of e-resources in Ayurved Medical College Libraries in Maharashtra. It was revealed that on daily basis, students use e-journal at an average of 12 hours per week. Achonna (2008) carried out a study on awareness, access and usage of E-journal by the students of College of Technology, Yaba, Nigeria and found that the use of e-journal resources was low among 
the students. In a related study on use of electronic information resources among the students and researchers of Faculty of Arts by Thanuskodi (2012), it was revealed that majority of the respondents used electronic resources for various purposes such as writing papers, studying, research purpose, updating knowledge and for examination. In a separate study in Ghana, Akuffo (2019) and Ankrah \& Acheampong (2017) revealed that students use electronic resources for research and assignments. However, Daramola (2016) reported low use of electronic resources among undergraduates in the Federal University of Technology, Akure, Nigeria while Ajibili (2013), Mawere \& Sai (2018) made same conclusion in similar studies conducted in Zimbabwe and Bingham respectively. In addition, Ojo \& Akande (2005), in a study on students' access, usage and awareness of electronic information resources at the University College Hospital, Ibadan, Nigeria, revealed that usage was not high. This was attributed to lack of information and retrieval skills to exploit the information resources. A study on students' perception of electronic resources in the University of Nigeria, Library Nzukka by Igbo \& Imo (2013), revealed a negative perception of EIR caused by low awareness, low level of utilization and user satisfaction. The Internet was identified as preferred medium of access in using electronic information resources (Kumar \& Singh, 2011) and crucial part of electronic services in academic institutions (Bhat \& Mudhol, 2014). Igun, (as cited in Adewole \& Batagara, 2013 p. 44) agreed with the assertion that Internet is satisfying students' hunger for knowledge and further research.

Previous studies have identified factors responsible for low use of EIR by students in academic libraries. Gurikar \& Gurikar (2015) posited that more users are eager to use electronic resources but were constrained by poor network connectivity and erratic power supply. The internet is the most preferred medium of access to electronic information resources. Of a truth students recognized the relevance of Internet in their academic pursuits but majority were not satisfied with limited Internet access service and irregular power supply on campus (Osinulu \& Okewale, 2012). In a study by Oghenetega (2014), it was found that student' low usage of digital information resources was due to non-availability of online databases, lack of formal training in internet skills, slow bandwidth and slow server. Other issues associated with low use of electronic resources among undergraduates in previous studies include lack of awareness, ineffective marketing strategy and inadequate training, (Ajibili, 2013; Igbo \& Imo, 2013; Daramola, 2016, Mawere \& Sai, 2018), lack of competence, poor infrastructure, low level of access and use of free online resources (Enwanta \& Nwalo, 2012, Adewole \& Batagarawa, 2013); uncooperative attitude of staff and loss of password (Bashorun et al., 2011; Yebowaah \& Plockey, 2017).

From the reviewed literature, it is established that electronic information resource is increasingly being embraced in academic libraries worldwide and adding value to learning as well as providing revolutionary library services. However, under-utilization, low awareness, inadequate infrastructure and facilities remain recurrent problems in the Nigerian university libraries. In view of the above, this study attempts to provide measures to improve effective use of EIR in the College of Health Sciences library in Ogun State.

\section{Methodology}

The study adopted the descriptive research design. The population comprised 200-500 level students in the faculties of Clinical, Pharmacy and Basic Medical Sciences Obafemi Awolowo College of Health Sciences (OACHS) Sagamu. Purposive sampling technique was used to select a sample of 200 users duly registered in the library in 2019/2020 academic session. It is considered that this category of students would have gone through library orientation and must have carried out several assignments for 
which they would have used the library. A structured questionnaire titled "Electronic Information Resources Awareness and Use Questionnaire (ERAUQ)" was used for data collection. A total of 200 copies of the questionnaire were administered and 174 were returned giving a response rate of $87.0 \%$ which was considered adequate for this study. Data collected were analyzed using frequencies, percentages, mean and standard deviation. The justification for the study is to evaluate and receive feedback from users of the resources with the aim of improving services and promoting usage of eresources. A comparative study across other disciplines in the other campuses is suggested for further research.

\section{Results}

Characteristics of respondents

Table 1: Distribution of Respondents based on Demographic Information

\begin{tabular}{|l|l|l|l|l|}
\hline $\mathbf{S} / \mathbf{N}$ & \multicolumn{2}{|l|}{ Variables } & Frequency & Percentage (\%) \\
\hline 1 & Gender & Male & 64 & 36.8 \\
& & Female & 110 & 63.2 \\
& & Total & 174 & 100.0 \\
\hline 2 & Faculty & Clinical Sciences & 41 & 23.6 \\
& & Pharmacy & 40 & 23.0 \\
& & Basic Medical Sciences & 93 & 53.4 \\
& & Total & 174 & 100.0 \\
\hline 3 & \multirow{2}{*}{ Discipline } & Medicine & 41 & 23.6 \\
& & Pharmacy & 40 & 23.0 \\
& & Physiology & 22 & 12.6 \\
& & Anatomy & 20 & 11.5 \\
& & Biochemistry & 15 & 8.6 \\
& & Nursing & 10 & 5.7 \\
& & Pharmacology & 25 & 14.4 \\
& & Chemical Pathology & 1 & 0.6 \\
& & Total & 174 & 100.0 \\
\hline 4 & \multirow{2}{*}{ Level } & 200 level & 65 & 37.4 \\
& & 300 level & 54 & 31.0 \\
& & 400 level & 51 & 29.3 \\
& & 500 level & 4 & 2.3 \\
& & Total & 174 & 100.0 \\
\hline 5 & Age Range & 17 to 19 years & 73 & 42.0 \\
& & 20 to 23 years & 85 & 48.9 \\
& & 24 to 26 years & 10 & 5.7 \\
& & 27 years and Above & 6 & 3.4 \\
& & Total & 100.0 \\
\hline
\end{tabular}

Table 1 provides information on the demographic characteristics of the respondents. The result revealed that there are more female (63.2\%) than male students (36.8\%) among the respondents. This may mean that there are more female than male students in the College. Also, the result revealed that majority of the respondents 93, (53.4\%) is from the Faculty of Basic Medical Sciences which may imply that there are more students in the Faculty of Basic Medical Sciences than every other faculty in the College. The distribution of the respondents across disciplines reveals that $23.6 \%$ are from Medicine, $23 \%$ are from Pharmacy, $14.4 \%$ are from Pharmacology and 12.6\% are from Physiology. Also, 11.5\%, 8.6\%, 5.7\%, and $0.6 \%$ of the respondents are found to be from Departments of Anatomy, Biochemistry, Nursing and Chemical Pathology respectively while majority of the respondents $(68.4 \%)$ are found to be in their second and third year of study ( $200 \& 300$ levels). The age distribution of the respondents show that majority of the respondents $(158,90.9 \%)$ are within the age range of $17-23$ years. This implies that there are more young students in the OACHS, Sagamu, Ogun State. 
Research question 1: What are the types of electronic information resources available in the library?

Table 2: Type of EIR available in the library

\begin{tabular}{|c|c|c|c|c|c|}
\hline $\mathbf{S} / \mathbf{N}$ & Electronic Information Resources & Yes (\%) & No (\%) & Mean & Std. Dev \\
\hline 1 & E-Books & $84(48.3)$ & $90(51.7)$ & 1.48 & .501 \\
\hline 2 & E-Journals & $74(42.5)$ & $100(57.5)$ & 1.43 & .496 \\
\hline 3 & Internet & $70(40.2)$ & $104(59.8)$ & 1.40 & .492 \\
\hline 4 & Electronic databases & $49(28.2)$ & $125(71.8)$ & 1.28 & .451 \\
\hline 5 & Theses/Dissertations & $41(23.6)$ & $133(76.4)$ & 1.24 & .426 \\
\hline \multirow[t]{2}{*}{6} & CD-ROM & $34(19.5)$ & $140(80.5)$ & 1.20 & .398 \\
\hline & Weighted Mean & \multicolumn{4}{|c|}{1.33} \\
\hline
\end{tabular}

Table 2 presents the result on the types of electronic information resources available and students awareness of their existence in OACHS Library. The finding shows that less than average of the respondents were aware of the availability of e-Books 84(48.3\%), e-journals 74 (42.5\%) and Internet 70 $(40.2 \%)$ as just a very few attested to their awareness of electronic databases 49(28.2\%), theses/dissertations $41(23.6 \%)$ and CD-ROM 34 (19.5\%) while e-books 90 (51.7\%); e-journals 100(57.5\%), Internet 104 (59.8\%), electronic databases 125 (71.8\%), theses and dissertations 133 (76.4) and CD-ROM $140(80.5 \%)$ respondent were not aware. There is a very low level of awareness on available electronic information resources, an indication of limited knowledge of the resources among the students. It can be deduced that the majority of the students were not familiar and therefore ignorant of the existence of the EIR. This issue may have been responsible for the low exploitation of the resources. This agrees with Dukper, Sakibu \& Athur 2018 \& Natarajan, et al. 2010). It also buttressed the assertion by Popoola (2008) that information availability may not necessarily translate to use.

Research question 2: What is the level of awareness of electronic information resources available for use among the students?

Table 3: Level of awareness of electronic information resources

\begin{tabular}{|l|l|l|}
\hline Level of Awareness & Frequency & Percentage (\%) \\
\hline High & 24 & 13.8 \\
\hline Moderate & 64 & 36.8 \\
\hline Low & 86 & 49.4 \\
\hline Total & $\mathbf{1 7 4}$ & $\mathbf{1 0 0 . 0}$ \\
\hline
\end{tabular}

Table 3 presents the result on the level of awareness of electronic information resources in the library among the respondents. The result shows that majority of the respondents 86, representing $49.4 \%$ indicated low level of awareness of electronic information resources. On the other hand, 64 representing $36.8 \%$ affirmed moderate/average level of awareness of electronic information resources in the library while only 24 representing $13.8 \%$ indicated high level of awareness. The implication of this is that there is a low level of awareness of EIR among majority of the students. The findings corroborate that of Dukper et al., (2018); Mawere \& Sai (2018); Daramola (2016); Igbo and Imo, (2013) as well as Ajibili (2013) who individually reported low level of awareness of electronic information resources among the undergraduates in tertiary institutions in Africa. This should be of grave concern to librarians considering the huge investments by way of subscription to electronic resources. The finding however negates that of Gakinbayo \& Ikojo-Odongo (2013) who revealed that many students were aware of electronic resources. 
Research question 3: For what purposes do students use electronic information resources?

Table 4: Purpose of use of electronic information resources by students

\begin{tabular}{|l|l|l|l|l|l|}
\hline $\mathbf{S} / \mathbf{N}$ & Purpose & Yes (\%) & No (\%) & Mean & Std. Dev \\
\hline 1 & To find relevant information & $122(70.1)$ & $52(29.9)$ & 1.70 & .459 \\
\hline 2 & For research activity & $114(65.5)$ & $60(34.5)$ & 1.66 & .477 \\
\hline 3 & For assignment & $101(58.0)$ & $73(42.0)$ & 1.58 & .495 \\
\hline 4 & To update lecture notes & $62(35.6)$ & $112(64.4)$ & 1.36 & .480 \\
\hline 5 & To study & $36(20.7)$ & $138(79.3)$ & 1.21 & .406 \\
\hline 6 & For Discussion & $34(19.5)$ & $140(80.5)$ & 1.20 & .398 \\
\hline 7 & To update oneself & $16(9.2)$ & $158(90.8)$ & 1.09 & .290 \\
\hline
\end{tabular}

The result on the purpose of use of electronic information resources by the respondents as presented in Table 4 revealed that finding relevant information 122(70.1\%), research activity $114(65.5 \%)$ and completing assignments $101(58.0 \%)$ topped the list of purposes for which the respondents surveyed used electronic information resources as affirmed by majority of the respondents. It can, therefore, be deduced from the results that finding relevant information, research activity and completing assignments were the major purposes for which students use electronic information resources. This implies that students recognized the significance of electronic information resources to academic works. The findings above are in consonance with the work of Tella, Ayeni \& Omoba (2007) who affirmed that electronic information resources promote scholarship. Similarly, the findings are also in line with the work of Thanuskodi (2012), who reported that students use EIR for various purposes which include writing papers, research and updating knowledge amongst others.

Research question 4: How frequently do the students use electronic information resources available in the library?

Table 5: Frequency of use of Electronic information resources

\begin{tabular}{|l|l|l|}
\hline Frequency & No of Respondents & Percentage \\
\hline Twice in a week & 38 & $21.84 \%$ \\
\hline Once in a week & 30 & $17.24 \%$ \\
\hline Occasionally & 43 & $24.71 \%$ \\
\hline Not at all & 63 & $36.21 \%$ \\
\hline Total & $\mathbf{1 7 4}$ & $\mathbf{1 0 0} \%$ \\
\hline
\end{tabular}

The table shows that $38(21.8 \%)$ of the respondents use e-resources twice in a week, followed by 30 $(17.2 \%)$ once in a week, $43(24.7 \%)$ occasionally while $66(37.9 \%)$ never used the resources at all. It can be deduced that there are more non-users of electronic information resources in the library. This finding validates that of Dukper, Sakibu \& Arthur (2018) and Natarajan, et al (2010) that regardless of the availability of a wide range of resources the frequency of use was abysmally low.

Research question 5: What are the problems hindering the use of electronic information resources by students?

Table 6: Problems hindering the use of electronic information resources

\begin{tabular}{|l|l|l|l|l|l|l|l|}
\hline S/N & Item Description & SA (\%) & Agree (\%) & $\begin{array}{l}\text { Disagree } \\
(\%)\end{array}$ & SD (\%) & $\begin{array}{l}\text { Mean } \\
\text { Std. } \\
\text { Dev. }\end{array}$ \\
\hline 1 & $\begin{array}{l}\text { Inadequate provision of } \\
\text { computers }\end{array}$ & $78(44.8)$ & $32(18.4)$ & $23(13.2)$ & $41(23.6)$ & 2.84 & 1.228 \\
\hline 2 & Erratic power supply & $60(34.5)$ & $26(14.9)$ & $30(17.2)$ & $58(33.3)$ & 2.51 & 1.271 \\
\hline
\end{tabular}




\begin{tabular}{|l|l|l|l|l|l|l|l|}
\hline 3 & Poor network & $47(27.0)$ & $37(21.3)$ & $33(19.0)$ & $57(32.8)$ & 2.43 & 1.203 \\
\hline 4 & Slow internet speed & $39(22.4)$ & $45(25.9)$ & $34(19.5)$ & $56(32.2)$ & 2.39 & 1.156 \\
\hline 5 & $\begin{array}{l}\text { Uncooperative attitude of library } \\
\text { staff }\end{array}$ & $27(15.5)$ & $35(20.1)$ & $48(27.6)$ & $64(36.8)$ & 2.14 & 1.084 \\
\hline 6 & Lack of training & $35(20.1)$ & $30(17.2)$ & $32(18.4)$ & $77(44.3)$ & 2.13 & 1.188 \\
\hline 7 & $\begin{array}{l}\text { Difficulty in finding relevant } \\
\text { information }\end{array}$ & $21(12.1)$ & $42(24.1)$ & $46(26.4)$ & $65(37.4)$ & 2.11 & 1.045 \\
\hline 8 & Lack of ICT knowledge & $31(17.8)$ & $24(13.8)$ & $33(19.0)$ & $86(49.4)$ & 2.00 & 1.163 \\
\hline 9 & Loss of password & $22(12.6)$ & $28(16.1)$ & $49(28.2)$ & $75(43.1)$ & 1.98 & 1.051 \\
\hline 10 & $\begin{array}{l}\text { Lack of time from } \\
\text { Difficulties in reading freen }\end{array}$ & $18(10.3)$ & $31(17.8)$ & $45(25.9)$ & $80(46.0)$ & 1.93 & 1.026 \\
\hline 11 & inadequate searching skills & $14(8.0)$ & $24(13.8)$ & $36(20.7)$ & $96(55.2)$ & 1.79 & 1.033 \\
\hline & Weighted Mean & & $29(16.7)$ & $29(16.7)$ & $102(58.6)$ & 1.74 & 1.007 \\
\hline
\end{tabular}

Table 6 presents the result of the problems hindering the use of electronic information resources by the respondents surveyed. The result revealed that a little above average of the respondents surveyed $110(53.2 \%)$ indicated inadequate provision of computers, just as about average number of the respondents surveyed (86. 49.4\%) indicated erratic power supply as a problem hindering their use of electronic information resources. Also, using the benchmark of 2.17 as decision rule, it can be inferred from the result that inadequate provision of computers $(\bar{X}=2.84)$, erratic power supply $(\bar{X}=2.51)$, poor network $(\bar{X}=2.43)$ and slow Internet speed $(\bar{X}=2.39)$ are major constraints to the use of electronic information resources among the respondents. The implication is that inadequate provision of computers and erratic power supply were the major constraints in the use of electronic information resources among students of Obafemi Awolowo College of Health Sciences, Sagamu. These findings affirmed the results of previous studies (Yebowaah \& Plockey, 2017; Igbo \& Imo, 2013).

\section{Conclusion and recommendations}

It is evident that provision of electronic resources is like a lifeline support that is adding values to learning and academic library services. However, the findings showed that a significant proportion of the respondents were not well-informed of the available electronic information resources which largely resulted to low awareness and usage. The low usage is attributed to inadequate computers, erratic power supply, poor network and slow internet speed. These findings are worrisome. The challenges militating against the effective use of EIR should be addressed promptly and decisively. Based on the findings, it is recommended that:

1. The librarians should engage in current awareness programme to bring new acquisitions to the attention of the students. This could be done using appropriate social media technology such as Blog or Instant Messaging (IM) to disseminate necessary information.

2. The Librarians could adopt a collaborative effort with Faculty members in organizing training on the use of electronic resources and specialized databases for staff and students across all the departments in the College.

3. Adequate number of computers should be provided. The computers provided should be enough to, at least, serve $25 \%$ of the students' population at a given period of time in the library.

4. An enabling environment should be provided with appropriate ICT that will guarantee the required internet speed with steady electricity supply. In the current situation where electricity 
supply is generally unstable, the library could explore providing alternative source of power supply such as solar energy (solar inverter).

\section{References}

Achonna, U. (2008). Awareness, access and usage of E-journal resources of the library by the students of Yaba College of Technology Yaba, Lagos Nigeria. Samaru Journal of Information Studies 8(1): 26-34.

Adewole, S. \& Batagarawa, S. A. (2013). The use of E-library in Umaru Musa Yar'adua University library. Middle Belt Journal of Library and Information Science 11(1): 43-62.

Ahmed, S. M. (2013). A survey of students' use of and satisfaction with university subscribed online resources in specialized libraries in developing countries. Library Hi Tech News. 3: 1-7.

Aina, L. R. (2014). Awareness, accessibility and use of electronic databases among academic staff of Babcock University Business School. Kuwait Chapter of Arabian Journal of Business Mangement Behaviour 3(6): 40-47.

Ajibili, M . G. (2013). Utilisation of e-library by undergraduate students in private university libraries: a case of Bingham University. Journal of Information Technologist 10(2):

Akuffo, M. N. (2019). Use of electronic resources by students in a premier postgraduate theological University of Ghana. South African Journal Information Management 21(1):

Ankrah, E \& Acheampong, E.K. (2017). Students'use of electronic resources in University of professional studies, Accra. Journal of Information Science, Systems and Technology1 (2):1126.

Bamidele, O. (2015). Assessment of undergraduates' utilization of electronic resources for academic tasks in universities in Ekiti State, Nigeria. Journal of Library, Educational Media and Information Studies 7 (6): 75-87.

Bhat, I., \& Mudhol, M. V. (2014). Use of e-resources by faculty members and students of SherE-Kashmir Institute of Medical Science (SKIMS). DESIDOC Journal of Library \& Information Technology, 34 (1): 7-20.

Bashorun, M. T, Isah, A. \& Adisa, M.Y. (2011). User perception of electronic resources in the University of Ilorin, Nigeria. Journal Emerging Trends Computer Information

Science 2 (11): 557-562.

Daramola, C. F. (2016). Perception and utilization of electronic resources by undergraduate students: the case of the Federal University of Technology Library, Akure. American Journal of Educational Research 4(5): 366-370.

Dukper, K.B. Sakibu, B. \& Arthur, B. (2018). Awareness and utilizationof electronic resources by students of Tamale Technical University, Ghana. Library Philosophy and Practice.Paper 2078.http://digitalcommons.unl.edu/libphilprac/2078.

Emwanta, M. \& Nwalo, K. I. N (2012). Influence of computer literacy and subject background on use of electronic resources by undergraduate students in universities in South-western Nigeria. International Journal of Library and Information Science 5(2):28-42. http://www.academicjournals.org/IJLIS 
Gakibayo, A., Ikoja - Odongo., J. R. \& Okello - Obura, C. (2013).Electronic information resources Utilization by Students in Mbarara University Library. Library Philosophy and Practice. Available at: http://digitalcommon.unl.edu/libphilpeac/869.

Gurikar, R. \& Gurikar, R. (2015). Use of library resources and services by Karnatak University research scholars: a case study. DESIDOC Journal of Library \& Information Technology 35 (5): 361 367.

Ibegwan, A., Ogunyade, T.O \& Ajuwon, A. G. (2013). Awareness and use of electronic information resources by academic staff of two Medical Colleges in Nigerian University.

Middlebelt Journal of Library and Information Science 11 (1): 74-91

IFLA, (2012). Key issues for e-Resource collection development: a guideforlibraries .https://www.ifla.org

Igbo, H. U \& Imo, N. T (2013). Students' perception of EIR in the university of Nigeria libraries.Compendium of NLA 2013 Conference papers at Calabar,Cross River State 9-14

Jogan, S. N. (2015). Access, awareness and use of electronic resources by postgraduate students in Gulbarga University. International Journal of Informative \& Futuristic Research 2(6):15401547

Kumar, A. (2009). Use and usage of electronic resources in business schools in India: FIIB. International Conference on Academic Libraries, 46, 573-578.

Kumar, S. B.Y. \& Kumar, G. T.(2010). Perception and usage of e-resources and the internet by Indian academics. The Electronic Library. 28 (1):137-56.

Kumar, S. \& Singh, M (2011). Access and use of electronic information resources by scientist of National Physical Laboratory in India: a case study. Singapore Journal of Library and Information Management 40, 33-40.

Kinengyere, A. A. (2007). The effect of information literacy on the utilization of electronic information resources in selected academic and research institutions in Uganda. The Electronic Library, 25(3): 328-341.

Mandale, S. R. (2019). E-resource usage in Ayurved Medical College libraries in Maharashtra. International Journal of Library and Information Studies 9 (4): 67-73.

Mawere, T \& Sai, K. O. (2018). Investigation on e-resources utilization among university students in a developing country: A case of Great Zimbabwe University. South African Journal of Information Management 20 (1):

Natarajan, K., Suresh, B., Sivaraman, P. \& Sevukan, P.(2010).Use and user perception of electronic resources in Annamalai University: a case study. ALIS 57 (1): 53-63

Oghenetega, I. (2014). Usage and awareness of E-Resources by lecturers in two selected Nigerian Universities. Journal of Library \& Information Science 3 (4): 761-774 
Okello-Obura, C. \& Magara, E. (2008). Electronic information access and utilization by Makere University students in Uganda. Evidence Based Library and Information Practice 3(3): 39-56.

Ojo, R. A. \& Akande, S. O. (2005). Student access, usage and awareness of electronic information resources at the university College Hospital, UniversityofIbadan, Nigeria.Lagos Journal of Library and Information Science 3(1): 16-24.

Osinulu, Lolade F. \& Okewale, Oluwatoyin S. (2012). A study of Internet access and usage among students in the faculties of Science Social and Management Sciences in a State University in Nigeria. International Journal of Information and Communication Technology (ICT) 9(1): 153-161.

Popoola, S. O. (2008). The use of information sources and services and its effect on the use research output of social sciences in Nigerian Universities. Library Philosophy and Practice. Retrieved from https://www.webpages.uidaho.edu/ mbolin/popoola.htm

Tella, A, Ayeni,C. O \& Omoba, R.O. (2007). Self-efficacy and use of electronic information as predictor of academic performance. Electronic Journal of Academic and Special Library $8(2)$

Thanuskodi, S. (2012). Use of E-resources by the students and researchers of Faculty of Arts, Annamalai University. International Journal of Library Science, 1 (1) 1 - 7.

Yebowaah, A. F. \& Plockey, D. D. F (2017). Awareness and use of electronic resources 